\title{
Study on synergistic effect of new function- alized Ag nanoparticles for intracellular drug uptake in cancer cells
}

\author{
Yanyan Zhou, Xuemei Wang* \\ State Key Lab of Bioelectronics (Chien-Shiung Wu Laboratory), Southeast University, Nanjing 210096, P. R. China \\ *Corresponding author:xuewang@seu.edu.cn
}

\begin{abstract}
In this study, we have explored the possibility of the application of the functionalized silver nanoparticles (Ag NPs) as drug carriers allied with anticancer drug daunorubicin (DNR) for efficient cancer chemotherapy. The results demonstrate that Ag NPs can enhance the intracellular drug DNR accumulation concentration in the leukemia K562 cells and thereby increase the killing effect on the leukemia K562 cells.
\end{abstract}

Key Words: DNR-Ag NPs nanocomposites, leukemia K562 cells, Drug delivery system

Citation: Y. Zhou, et al. Study on synergistic effect of new functionalized Ag nanoparticles for intracellular drug uptake in cancer cells. Nano Biomed. Eng. 2010, 2(4), 208-213. DOI: 10.5101/nbe.v2i4.p208-213.

\section{Introduction}

It is well known that cancer is one of the major killers to human health, and its morbidity and mortality is in the upward trend in recent years, therefore, early diagnosis and effective treatment is very important. Up to now, chemotherapy is the primary means of cancer therapy. However, there are lots of problems, such as too low intracellular concentration of anticancer drug. It is necessary to improve the effective drug concentration in cancer cells, achieve target identification and reduce the damage to other organs. Recent years, with the rapid development of nanotechnology, there are more and more nanomaterials used in cancer treatment and provide a new road for cancer therapy [1-4].

Nano druge delivery systems with controlled-release, drug targeting, as well as significantly increase the bioavailability of drugs, greatly overcome the weaknesses of traditional drug delivery [5-9]. Some literatures reported that anticancer drugs and poly-nanoparticle complexes can increase the anticancer drug accumulation in tumor cells so as to achieve a better therapeutic effect $[10,11]$.

Silver nanoparticle (Ag NP) is a kind of metal nanomaterials with unique electrical, optical, catalytic and other properties [12-14], which demonstrates important application in many fields. With the feature of excellent bio-compatibility, Ag NPs play an important role in biomedical applications [15-19]. In this contribution, we have explored the combination of the functionalized Ag nanoparticles with anticancer drugs daunorubicin (DNR) to form a new biocompatible nanocomposite to facilitate the cellular drug uptake in leukemia cells. Our results show that the nanocomposites can effectively enhance the accumulation of anticancer drugs into the cancer cells, thereby greatly increasing the intracellular drug concentration in leukemia cells and enhancing the lethal effect on cancer cells.

\section{2 . Experimental Section}

\subsection{Reagents}

Functionalized Ag nanoparticles capped with tetraheptylammonium were fabricated by electrochemistry deposition as previously reported in the literature [20], and the average size of the synthesized Ag nanoparticles was about $10 \mathrm{~nm}$ characterized by using JEM-2100 transmission electronic microscopy at room temperature $\left(20 \pm 2{ }^{\circ} \mathrm{C}\right)$. Daunorubicin was purchased from Nanjing pharmacy factory (analytical grade), and stock solutions were freshly prepared by sterilized phosphate buffer solution (PBS) $\left(0.1 \mathrm{molL}^{-1}, \mathrm{pH}=7.2\right)$ and stored in the dark at $4^{\circ} \mathrm{C}$. All other reagents were analytical grade. 


\subsection{Cell Culture}

The leukemia K562 cell lines were cultured in a flask in RPMI 1640 medium (GIBCO) supplemented with 10\% fetal calf serum (FCS, Sigma), penicillin (100 IU mL $\mathrm{mL}^{-1}$ ), and streptomycin $\left(100 \mu \mathrm{g} \mathrm{mL} L^{-1}\right)$ at $37^{\circ} \mathrm{C}$ in a humidified incubator containing $5 \% \mathrm{CO}_{2}$.

\subsection{In vitro cytotoxicity study of functionalized Ag NPs}

The viability of cells was measured by the MTT method. First of all, leukemia K562 cells in the logarithmic phase were seeded in 96-well plates at a density of $1.0 \times 10^{4}$ cells/well, and incubated overnight at $37^{\circ} \mathrm{C}$ in a $5 \% \mathrm{CO}_{2}$ humidified environment. Then the cells were treated with Ag nanoparticles for $24 \mathrm{~h}$. The final concentration of Ag nanoparticles in each well was 3.125, 6.25, 12.5, 25, 50, $100 \mu \mathrm{g} \mathrm{ml}^{-1}$ (dissolved with RPMI 1640 medium), respectively. Control group was cultivated on the same conditions without Ag nanoparticles. After all samples were cultured for $24 \mathrm{~h}, 20 \mu \mathrm{L}$ of $5 \mathrm{gL}^{-1}$ MTT was added and incubated for additional $4 \mathrm{~h}$. Then, the plates were centrifuged at $1000 \mathrm{rpm}$ for $10 \mathrm{~min}$, and the supernatant was discarded lightly, followed by addition of $150 \mu \mathrm{L}$ of DMSO into each well and gentle shaking in the shaker incubator at $37^{\circ} \mathrm{C}$ for $10 \mathrm{~min}$. After this, the optical density (OD) was recorded at $492 \mathrm{~nm}$. Cell viability was expressed as follows: cell viability $(\%)=[\mathrm{A}]$ test $/[\mathrm{A}]$ control $\times 100 \%$, where $[\mathrm{A}]$ represents the absorbance value at $492 \mathrm{~nm}$. Each experiment was repeated at least three times.

\subsection{The concentration changes of intracellular DNR}

\subsubsection{Fluorescence microscopy}

The leukemia K562 cells $\left(5 \times 10^{5}\right.$ cells $\left.\mathrm{mL}^{-1}\right)$ in the logarithmic phase were cultured with DNR molecules $\left(1.8 \times 10^{-7} \mathrm{molL}^{-1}\right)$ and DNR - Ag NPs nanocomposite (DNR $1.8 \times 10^{-7} \mathrm{molL}^{-1}$, Ag NPs $2.0 \mathrm{mgL}^{-1}$ ) for $2 \mathrm{~h}$, respectively. After incubation, the cells were collected by centrifugation at $1000 \mathrm{rpm}$ for $10 \mathrm{~min}$, and gently tossed away the supernatant solution, then the cell pellets gently were washed with PBS buffer at least three times. $15 \mu \mathrm{L}$ of a cell suspension was dropped on a $0.17 \mathrm{~mm}$ thick glass coverslip, and then irradiated by a laser beam $(488 \mathrm{~nm})$, on an objective-type total internal reflection fluorescence microscope (TIRFM). The incident angle of the laser beam was first adjusted to produce total internal reflection of the laser beam by the $60 \times$ TIRFM oil-immersion objective lens of the inverted microscope (NikonTi Microscope). The images of the cancer cells were acquired by focusing the objective down to the coverslip.

\subsubsection{The proliferation inhibition of DNR-Ag NPS complexes on K562 cells}

We have further explored the drugs loading capacity of Ag NPs on K562 leukemia cells by the MTT method. First of all, leukemia K562 cells in the logarithmic phase were seeded in 96-well plates at the density of $1.0 \times 10^{4}$ cells/well, and incubated overnight at $37^{\circ} \mathrm{C}, 5 \% \mathrm{CO}_{2}$ saturated moist air. Then the cells were treated with DNRAg NPs complexes $\left(3.8 \times 10^{-7} \mathrm{molL}^{-1} \mathrm{DNR}\right.$ and $2.0 \mathrm{mgL}^{-1}$
Ag NPs), at the same time, the control group was also cultivated with DNR $\left(3.8 \times 10^{-7} \mathrm{molL}^{-1}\right)$ alone under the same condition. After all samples were cultured for $24 \mathrm{~h}$, $20 \mu \mathrm{L}$ of $5 \mathrm{mg} \mathrm{mL}^{-1}$ MTT was added and incubated for additional $4 \mathrm{~h}$. Subsequently, the plates was centrifuged at $1000 \mathrm{rpm}$ for $10 \mathrm{~min}$ and the supernatant was discarded, followed by addition of $150 \mathrm{~mL}$ of DMSO into each well and gentle shaking in the shaker incubator at $37^{\circ} \mathrm{C}$ for $10 \mathrm{~min}$. After this, the optical density (OD) was recorded at $492 \mathrm{~nm}$. Cell inhibition rates were calculated by the following formula: $(1-[\mathrm{A}]$ test $/[\mathrm{A}]$ control $) \times 100 \%$, where [A] representative of the absorbance values of each hole at $492 \mathrm{~nm}$. Each experiment was repeated at least three times independently.

\section{5 the concentration changes of DNR in the extracellular cancer cells}

\subsubsection{Electrochemical Analysis}

Differentialpulse voltammetric (DPV) study was performed on a CHI660b electrochemical workstation to detect the extracellular concentration changes of DNR in the cancer cells. All measurements were carried out at room temperature $\left(20 \pm 2^{\circ} \mathrm{C}\right)$ in a three component electrochemical cell consisting of a glassy carbon electrode as working electrode, a Pt wire as the counter electrode and an $\mathrm{Ag}$ wire electrode as the reference electrode. DNR $3.8 \times 10^{-5} \mathrm{molL}^{-1}$ and Ag NPs $10 \mathrm{mgL}^{-1}$ were mixed in PBS $\left(0.01 \mathrm{molL}^{-1}, \mathrm{pH}=7.2\right)$ at $4{ }^{\circ} \mathrm{C}$ overnight, DNR and silver nanoparticles could selfassemble as the DNR-Ag NPs nanocomposites. The leukemia K562 cells were separated from suspension by centrifugation, and washed with $\mathrm{PBS}\left(0.01 \mathrm{molL}^{-1}\right.$, $\mathrm{pH}=7.2)$ twice; after that the cells $\left(5 \times 10^{5}\right.$ cells $)$ were recultured with the nanocompouds and aloned anticancer drug DNR for $2 \mathrm{~h}$, respectively.

\subsubsection{UV-Vis absorption spectroscopic assay}

UV-Vis absorption spectroscopy was performed on Hitachi U-4100, and all measurements were carried out at room temperature $\left(20 \pm 2^{\circ} \mathrm{C}\right)$. DNR $1.9 \times 10^{-5} \mathrm{molL}^{-1}$ and $\mathrm{Ag}$ NPs $5 \mathrm{mg} \mathrm{L}^{-1}$ were mixed in PBS (0.01 molL $\left.^{-1}, \mathrm{pH}=7.2\right)$ at $4{ }^{\circ} \mathrm{C}$ overnight, then DNR and Ag NPs could selfassemble as DNR-Ag NPs nanocomposites. The cells were separated from cell suspension by centrifugation and washed two times with PBS (0.01 $\left.\mathrm{molL}^{-1}, \mathrm{pH}=7.2\right)$. After this, $5 \times 10^{5}$ cells were resuspended with DNR-Ag NPs nanocomposites and anticancer drug DNR alone for $2 \mathrm{~h}$, respectively.

\subsection{Statistical analysis}

Experimental data were expressed as the means \pm SD (standard deviation) at least three parallel experiment. Student's t-test analysis was used for significance, $\mathrm{p}<0.05$ is considered significant.

\section{3 . Results and discussion}

\subsection{The TEM characterization of Ag NPs}

In this work, the Ag NPs was observed by TEM to 


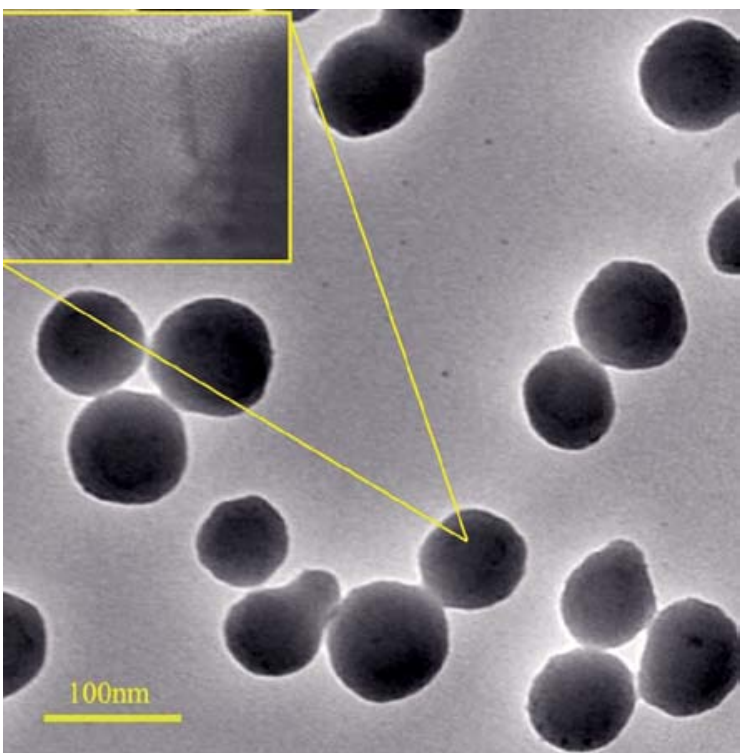

Figure 1 TEM image of the Ag nanoparticles

observe the surface crystal structure. As shown in Figure 1, the particles have a good crystal structure, lattice spacing is $0.195 \mathrm{~nm}$.

\subsection{Cytoxicity assay of Ag NPs on leukemia K562 cancer cells}

Initially, we explored the cytotoxic effect of Ag NPs on the K562 leukemia cell lines. The results showed that the functionalized Ag NPs on the K562 cells perform a dose-dependent toxicity. At high concentrations, the nanoparticles inhibited the K562 cells apparently, while the cells have little effect at low concentrations and the relevant IC50 value is $20.5 \mathrm{mg} \mathrm{L}^{-1}$.

\subsection{The Ag NPs effect on intracellular anticancer drug concentration change in leukemia $K 562$ cells}

\subsubsection{TIRFM of Ag NPs on K562 cancer cells}

The cellular interaction of fuctionalized Ag NPs with leukemia K562 cells were explored and visualized by TIRFM. As shown in Figure3, the TIRFM images of basal plasma membrance showed that the intracellular fluorescence of DNR on the K562 cells in the present and absence of Ag NPs. As DNR can produce fluorescence at $480 \mathrm{~nm}$ excitation wavelength, the intracellular DNR fluorescence intensity is proportional to the number of cells uptake. The results show that after incubated with DNR-Ag NPs nanocomposites, the relative fluorescence intensity of K562 cells (Figure 3b) is stronger than the that of cells cultured with DNR alone (Figure 3 a). Meanwhile, Figure $3 \mathrm{~b}$ shows the correspionding fluorescence intensity of intracellular DNR, under the role of nano-drugs complexes, the cell fluorescence intensity is much stronger than that incubated with daunorubicin alone, which has increased by about $90 \%$, indicating that the functionalized silver nanoparticles could facilitate more daunorubicin entering into K562 cells. The results demonstrated that the existence of functionlized Ag nanoparticles can significantly improve the membrane's permeability, thus help chemotherapy drugs to accumulate into the cell interior, promote cell uptake of

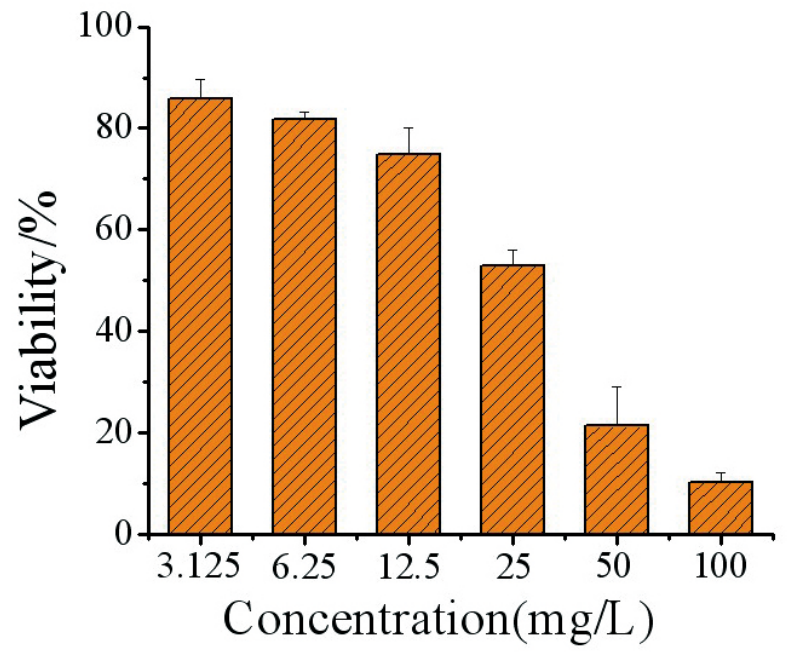

Figure 2 Cell viability of different concentrations of Ag NPs on K562 cells, data are mean $\pm \mathrm{SD}$, error bars indicate standard deviation.

DNR, enhance effective drug concentration within the cell to increase the proliferation of drugs on the target cell inhibition. Therefore, these Ag nanoparticles could efficiently improve the intracellular drug concentration to kill the cancer cells in relative chemotherapy.

\subsubsection{Evaluation of proliferation synergistic inhibition of Ag NPs on K562 cells - MTT analysis}

Based on the above study, we further examined the cell proliferation inhibition effect of $\mathrm{Ag}$ nanoparticles on leukemia K562 cells by using biological MTT assay. Considering the biological security, we adopted the safe concentration of relevant nanocomposites. As shown in Figure 4, MTT assay showed that when co-cultured K562 cells with $2.0 \mu \mathrm{g} \mathrm{mL}^{-1}$ of $\mathrm{Ag}$ nanoparticles and 3.8 $\times 10^{-7} \mathrm{molL}^{-1} \mathrm{DNR}$, the cell proliferation inhibition was significantly stronger than that of pure drug's (i.e., Ag nanoparticles or DNR alone) effect on the proliferation rate of K562 cells. It is observed that the proliferation inhibition rate of $2.0 \mu \mathrm{g} \mathrm{mL}{ }^{-1} \mathrm{Ag}$ nanoparticles or 3.8 $\times 10^{-7} \mathrm{molL}^{-1}$ DNR alone on K562 cells was 9\%, 12\%, respectively, while at the same concentration of $\mathrm{Ag}$ nanoparticles combined with DNR, its inhibition of K562 cell proliferation was increased to $36 \%$. Therefore, the proliferation inhibition rate of DNR-Ag NPs nanocomposites on K562 cells was significantly improved when compared with the single anticancer drug effect.

\subsection{Study on the extracellular concentration changes of DNR outside leukemia K562 cancer cells}

\subsubsection{Electrochemical assay}

In order to compare the cellular behavior under different conditions, we have used the electrochemical study to investigate the interaction between DNR and leukemia K562 cells in the absence and presence of functionlized Ag nanoparticles. As shown in Figure 5, the DPV study of DNR residues outside leukemia K562 cells in the absence and presence of Ag nanoparticles. The results indicated that the redox current of the DNR residues outside leukemia cells in the presence of Ag NPs (Figure 5, curve c) had decreased more considerably than that in the absence of Ag NPs (Figure 5, curve b), and meanwhile, 

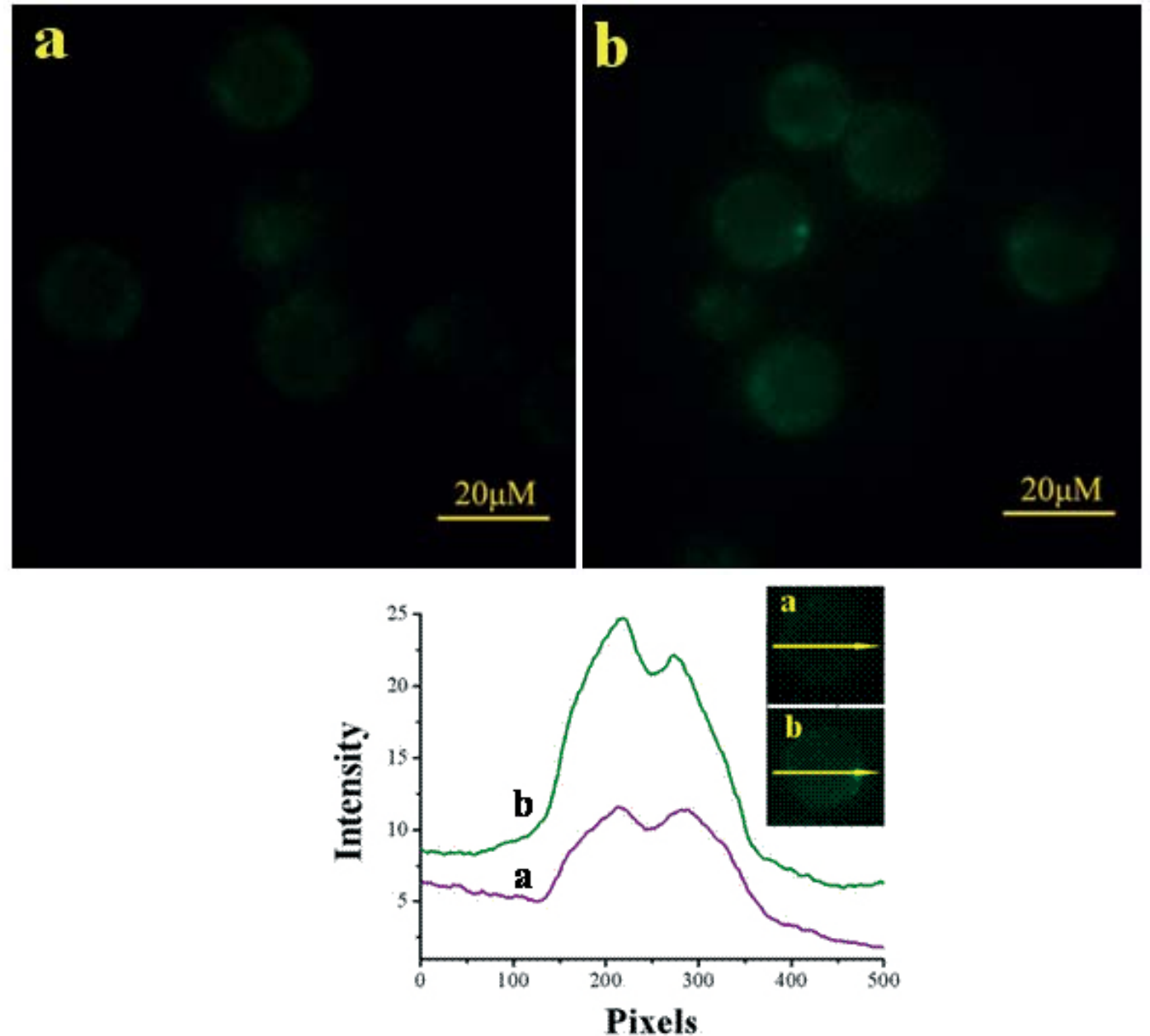

Figure 3 The TIRFM images of K562 cancer cells after incubation with DNR (a) and K562/A02 cancer cells after incubation with DNR-Ag NPs (b) for $2 \mathrm{~h}$.

there was an apparent positive shift of the peak potentials (Figure 5, curve c). It is evident that Silver nanoparticles could be utilized as an effective drug vector, enhancing anti-cancer drug in the tumor cells of cell concentration within the accumulation. From the above results, it is noted that the decrease in the DPV currents was directly related to the amount of drug uptake in the cancer cells. These observations are consistent with those of our fluorescence microscopy studies, indicating an important synergistic effect of the functionalized Ag nanoparticles on facilitating the accumulation of DNR in leukemia cells, demonstrating that functionalized Ag nanoparticles may act as an effective drug carrier.

\subsubsection{UV-Vis absorption spectroscopy study}

The UV-Vis absorption spectroscopy of the DNR residues after treated with leukemia K562 cells in the absence and present of functionlized $\mathrm{Ag}$ nanoparticles also afforded additional evidence for the cellular interaction behavior. As shown in Figure 6, it was obvious that when compared with the K562 cells cultured with DNR alone, the absorbance of the DNR residues outside K562 cells cultured with DNR-Ag nanocomposites remarkably decreased. The absorption peak of the DNR residues outside leukemia K562 cells was reduced by $20 \%$ in the absence of the nanoparticles and $46 \%$ in the presence of the DNR-Ag nanocomposites. As the concentration of daunorubicin in each group is the same, thus the results indicate that the synergy of silver nanoparticles could promote more DNR into leukemia cells, and lead to the significantly decrease of the extracellular daunorubicin.

In summary, in this study we have explored the potential application of functionalized Ag nanoparticles in cancer chemotherapy. The results demonstrate that the synergistic effect of the Ag nanoparticles can carry more

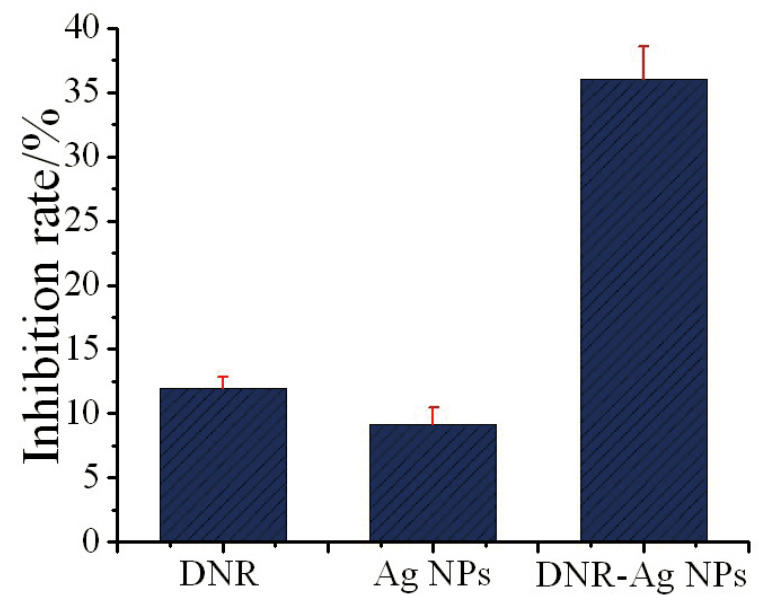

Figure 4 MTT assay on the inhibition rate of leukemia K562 cells after treated with DNR $\left(3.8 \times 10^{-7} \mathrm{molL}^{-1}\right)$ in the absence and presence of 2.0 $\mu \mathrm{g} \mathrm{mL}{ }^{-1}$ of Ag nanoparticles, respectively. Here, and $\mathrm{p}$ values $<0.05$. Error bars indicate \pm SD. 


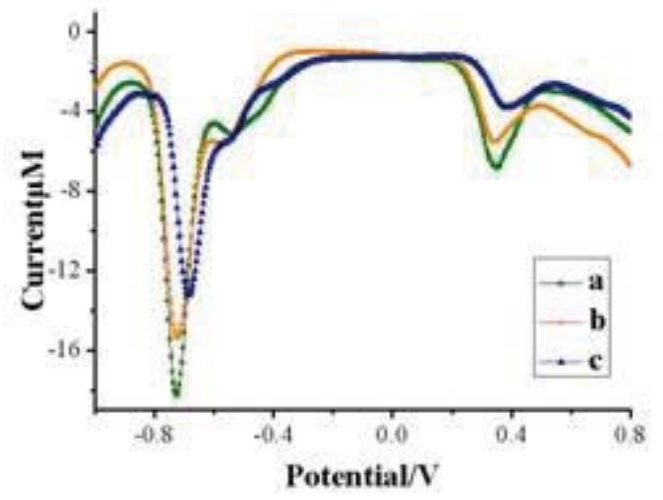

Figure 5 DPV study of DNR residues outside K562 cells after incubating for $2 \mathrm{~h}$ in the absence and presence of Ag NPs. (a) DNR (3.8 $\left.\times 10^{-5} \mathrm{molL}^{-1}\right)$; (b) DNR $\left(3.8 \times 10^{-5} \mathrm{molL}^{-1}\right)$ and cells; (c) DNR $\left(3.8 \times 10^{-5}\right.$ molL $\left.\mathrm{L}^{-1}\right)$ and cells exposed to Ag NPs $\left(10 \mathrm{mgL}^{-1}\right)$. Pulse amplitude: $0.05 \mathrm{~V}$; pulse width: $0.05 \mathrm{~s}$; pulse period: $0.2 \mathrm{~s}$.

drug DNR molecules into cancer cells and thus increase the intracellular drug concentration inside the target cells. The mechanism of synergestic effect may be attributed to the interaction of the functionalized Ag nanoparticles with target cells, leading to the cell membrane structure change and increase membrane permeability. With the specific properties and activities of the nanoparticles, the $\mathrm{Ag}$ nanoparticles can be used as drug carriers, effectively facilitate anticancer drugs to enter into cancer cells and improve the drug concentration in the tumor cells. Thus, the function of $\mathrm{Ag}$ nanoparticles has the potential and important application in cancer clinical treatment.

\section{Acknowledgments}

This work has been supported by National Nature Science Foundation of China (90713023), Doctoral Fund of Ministry of Education of China (20090092110028), the Graduate Research and Innovation Program of Jiangsu Province, National High Technology Research and Development Program (2007AA022007), National Key Basic Research Program (2010CB732404), Visiting Scholar Foundation of Key Laboratory of Biorheological Science and Technology (Chongqing University), Ministry of Education, and the Natural Science Foundation of Jiangsu Province (BK2008149).

\section{References}

1. Sternberg C N, Donat S M, Bellmunt J, et al. Chemotherapy for bladder cancer: Treatment guidelines for neoadjuvant chemotherapy.bladder preservation, adjuvant chemotherapy. and metastatic cancer. Urology. 2007;69:62-79. doi:10.1016/ j.urology.2006.10.041

2. Etzioni D A, El-Khoueiry A B, Beart R W. Rates and predictor of chemotherapy use for stage III colon cancer. Cancer. 2008; 113:3279-3289. doi:10.1002/cncr.23958

3. Alivisatos P. The use of nanocrystals in biological detection. Nat. Biotechnol. 2004;22:47-52. doi:10.1038/nbt927

4. Kim S, Lim Y T, Soltesz E G, et al. Near-infrared fluorescent type II quantum dots for sentinel lymph node mapping. Nat. Biotechnol.2004;22:93-97. doi:10.1038/nbt920

5.Taton T, Mirkin C, Letsinger R. Scanometric DNA array detection with nanoparticle probes. Science. 2000;289:17571760.doi:10.1126/science.289.5485.1757

6. Cui Y, Wei Q, Park H, et al. Nanowire nanosensors for highly sensitive and selective detection of biological and chemical species. Science. 2001;293:1289-1292. doi:10.1126/science. 1062711

7.Chen R J, Bangsaruntip S, Drouvalakis K A, et al.Noncovalent functionalization of carbon nanotubes for highly specific electronic biosensors. Proc. Natl. Acad. Sci. U. S. A. 2003;100:

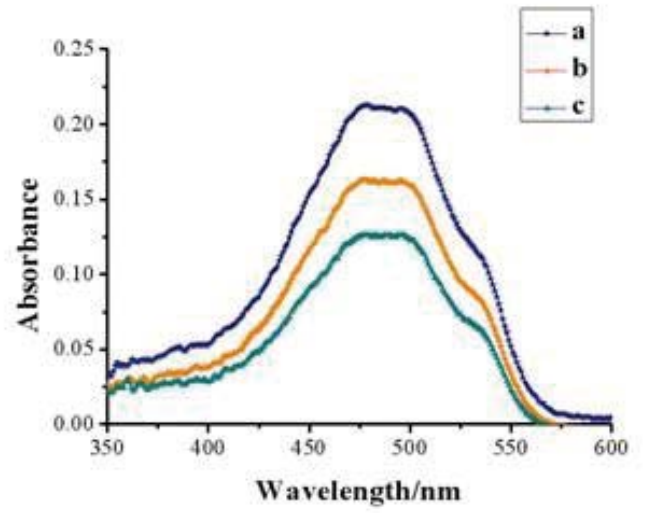

Figure 6 UV-Vis absorption spectra of DNR after the treatment with leukemia K562 cells in the absence and presence of Ag NPs for $2 \mathrm{~h}$. (a) DNR $\left(1.9 \times 10^{-5} \mathrm{molL}^{-1}\right)$; (b) DNR $\left(1.9 \times 10^{-5} \mathrm{molL}^{-1}\right)$ and cells; (c) DNR $\left(1.9 \times 10^{-5} \mathrm{molL}^{-1}\right)$ and cells exposed to $\operatorname{Ag} \operatorname{NPs}\left(5 \mathrm{mgL}^{-1}\right)$.

4984-4989. doi:10.1073/pnas.0837064100

8.Sahoo S K, Labhasetwar V. Nanotech approaches to drug delivery and imaging. Drug Discov. Today. 2003;8:1112-1120. doi:10.1016/S1359-6446(03)02903-9

9.Sunderland C J, Steiert M, Talmadge J E, et al. Targeted nanoparticles for detecting and treating cancer. Drug Dev. Res., 2006;67:70-93. doi:10.1002/ddr.20069

10.Orive G, Gascon A R, Hernandez R M, et al. Techniques: new approaches to the delivery of biopharmaceuticals. Trends. Pharm. Sci. 2004;25:382-387. doi:10.1016/j.tips.2004.05.006

11.Gu F X, Karnik R Wang A Z, et al. Targeted nanoparticles for cancer therapy. Nano Today, 2007;2:14-21. doi:10.1016/ S1748-0132(07)70083-X

12.Fahmy T M, Samstein R M, Harness C C, et al. Surface modification of biodegradable polyesters with fatty acid conjugates for improved drug targeting. Biomaterials. 2005; 26:5727-5736. doi:10.1016/j.biomaterials.2005.02.025

13.Lambert G, Fattal E, Pinto-alphandary H, et al.Polyisobutylcyanoacrylate nanocapsules containing an aqueous core as a novel colloidal carrier for the delivery of oligonucleotides. Pharm. Res. 2000;17:707-714. doi:10.1023/A:1007582332491

14. Mitra S, Gaur U, Ghosh P C, et al. Tumour targeled delivery of encapsulated dextran-doxorubicin conjugate using chitosan nanoparticles as carrier. J. Controlled Release. 2001;74:317323. doi:10.1016/S0168-3659(01)00342-X

15.Ferrando R, Jellinek J, Johnston R L. Nanoalloys: from theory to applications of alloy clusters and nanoparticles. Chem. Res. 2008;108; 845.

16.Ferrer D, Torres-Castro A, Gao X, et al. Three-layer Core/ Shell structure in $\mathrm{Au}-\mathrm{Pd}$ bimetallic nanoparticles. Nano Lett., 2007;7:1701-1705. doi:10.1021/n1070694a

17.Molenbroek A M, Norskov J K, Clausen B S. Structure and reactivity of $\mathrm{Ni}-\mathrm{Au}$ nanoparticle catalysts. J. Phys. Chem. $B$, 2001;105:5450-5458. doi:10.1021/jp0043975

18.Song M, Zhang R Y, Dai Y Y, Gao F, Chi H M, Lv G, et al.The in vitro inhibition of multidrug resistance by combined nanoparticulate titanium dioxide and UV rradiation. Biomaterials 2006; 27:4230-8. doi:10.101zj.biomaterials.z2006.03.021

19.Castellano J J, Shafii S M, Ko F, et al.Comparative evaluation of silver-containing antimicrobial dressings and drugs. Int. Wound J., 2007;4:114-122. doi:10.1111/j.1742-481X.2007.00316.X

20.Wang X M, Zhang R Y, Wu C H, Dai Y Y, Song M, Gutmann S, et al. The application of $\mathrm{Fe} 3 \mathrm{O} 4$ nanoparticles in cancer research: a new strategy to inhibit drug resistance. J. Biomed. Mater. Res. A. 2007;80: 852-60. doi:10.1002/jbm.a.30901

21.Alt V, Bechert T, Steinrucke P, et al. An in vitro assessment of the antibacterial properties and cytotoxicity of nanoparticulate silver bone cement. Biomaterials. 2004;25:4383-4391. doi:10. 1016/j.biomaterials.2003.10.078

22. Braydich-Stolle L, Hussain S, Schlager J J, et al. In vitro cytotoxicity of nanoparticles in mammalian germline stem cells. Toxicol. Sci. 2005;88:412-419. doi:10.1093/toxsci/kfi256

23.Hussain S M, Hess K L, Gearhart J M, et al. In vitro toxicity 
published online 15 December, 2010. 19:975-983. doi:10.1016/j.tiv.2005.06.034

24.Hussain S M, Javorina A K, Schrand A M, et al. The interaction of manganese nanoparticles with PC-12 cells induces dopamine depletion.Toxicol. Sci. 2006; 92:456-463.doi:10.1093/toxsci/ kfl020

Received 15 November, 2010; accepted 6 December, 2010;
Copyright: (c) 2010 Yanyan Zhou, et al. This is an openaccess article distributed under the terms of the Creative Commons Attribution License, which permits unrestricted use, distribution, and reproduction in any medium, provided the original author and source are credited. 